\title{
Perkembangan Bahasa Anak dan Implikasinya dalam Pembelajaran
}

\author{
M. Syahran Jailani \\ Fakultas Tarbiyah dan Keguruan UIN Sulthan Thaha Saifuddin Jambi \\ E-mail: m.syahran@ymail.com
}

\begin{abstract}
This article aims to discuss the importance of language, where language is the ability to communicate with others. Language is an essential factor that distinguishes humans from animals. Language is closely related to individual thinking development. The development of individual thinking appears in the development of language, namely the ability to form understanding, compile opinions and draw conclusions. Whereas, development is a process that must be experienced by each individual, this development is qualitative and related to maturity and systematic. Language development in children is very important because through language, children can express thoughts, so that others understand it and create a social relationship. So, it is not surprising that language is considered as an indicator of a child's success.
\end{abstract}

Keywords: child development; language; think ability.

\begin{abstract}
Abstrak: Artikel ini bertujuan untuk membahas pentingnya bahasa, dimana bahasa merupakan kemampuan untuk berkomunikasi dengan orang lain. Bahasa merupakan faktor hakiki yang membedakan manusia dengan hewan. Bahasa erat kaitannya dengan perekembangan berfikir individu. Perkembangan berfikir individu tampak dalam perkembangan bahasanya yaitu kemampuan membentuk pengertian, menyusun pendapat dan menarik kesimpulan. Sedangkan, perkembangan merupakan suatu proses yang pasti dialami setiap individu, perkembangan ini adalah bersifat kualitatif dan berhubungan dengan kematangan serta sistematis. Perkembangan bahasa pada anak sangat penting karena melalui bahasa, anak dapat mengekspresikan pikiran, sehingga orang lain memahaminya dan menciptakan suatu hubungan sosial. Jadi, tidaklah mengherankan bahwa bahasa dianggap sebagai salah satu indikator kesuksesan seorang anak.
\end{abstract}

Kata-kata kunci: perkembangan anak; bahasa; kemampuan berfikir.

\section{Pendahuluan}

Setiap insan memiliki potensi yang sama untuk menguasai bahasa. Proses dan sifat penguasaan bahasa setiap orang berlangsung dinamis dan melalui tahapan berjenjang. Manusia mengawali komunikasinya dengan dunia sekitarnya melalui bahasa tangis. Seorang bayi melatih bahasa tersebut dengan mengkomunikasikan segala kebutuhan dan keinginannya. Sejalan dengan perkembangan kemampuan serta kematangan jasmani terutama yang berkaitan dengan proses bicara, komunikasi tersebut makin meningkat dan meluas. Misalnya: dengan orang di sekitarnya, lingkungan dan berkembang dengan orang lain yang baru dikenal dan bersahabat dengannya. 
Perkembangan bahasa tersebut selalu meningkat sesuai dengan meningkatnya usia anak. Pada masa anak-anak perkembangan bahasa sangatlah penting. Perkembangan bahasa pada anak-anak sangat penting karena anak dapat mengembangkan kemampuan sosialnya (social skill) melalui berbahasa. Keterampilan bergaul dalam lingkungan sosial dimulai dengan penguasaan kemampuan berbahasa. Melalui bahasa, anak dapat mengekspresikan pikirannya menggunakan bahasa sehingga orang lain dapat menangkap apa yang dipikirkan oleh anak dan menciptakan suatu hubungan sosial. Pada saatnya anak akan dapat berkembang dan tumbuh menjadi pribadi yang bahagia karena dengan mulai berkomunikasi dengan lingkungan, bersedia memberi dan menerima segala sesuatu yang terjadi di lingkungannya. Proses perkembangan tersebut melalui berbagai tahapan-tahapan perkembangan bahasa anak, mulai kanak-kanak sampai dengan penguasaan usia sekolah. Dalam tahapan penguasaan bahasa inilah peran orang tua sebagai orang terdekat sangat dibutuhkan. Orang tua sebaiknya selalu memperhatikan perkernbangan tersebut, sebab pada masa ini sangat menentukan prosesseorang anak dalam bersosialisasi maupun belajar. Hal ini dapat. dilakukan dengan memberi contoh yang baik, memberikan motivasi pada anak untuk belajar dan scbagainya.

Masa perkembangan bicara dan bahasa yang paling intensif pada manusia terletak pada masa usia dini, tepatnya pada tiga tahun dari hidupnya, yakni suatu periode dimana otak manusia berkembang dalam proses mencapai kematangan. ${ }^{1}$ Masa usia dini merupakan masa keemasan (golden age) di sepanjang rentang usia perkembangan manusia. Montessori menyatakan bahwa masa tersebut merupakan periode sensitif (sensitive period), di mana anak secara khusus mudah menerima stimulus-stimulus dari lingkungannya. ${ }^{2}$

Perkembangan kemampuan berbahasa anak merupakan suatu proses yang secara berturut-turut dimulai dari mendengar, selanjutnya, berbicara, membaca dan menulis. Adapun perkembangan dari setiap kemampuan pada anak usia Taman Kanak-Kanak (4 - 6 tahun), adalah sebagai berikut.

\section{Kemampuan Mendengar}

Kemampuan mendengar anak-anak harus dikembangkan karena berkenaan dengan upaya memahami lingkungan mereka. Agar mereka belajar untuk mengembangkan kemampuan tersebut, mereka harus menerima masukan informasi dan mengolahnya. Menurut Cassel dan Jalongo, mendengarkan dan memahami informasi adalah langkah inti dalam memperoleh pengetahuan. ${ }^{3}$

Anak usia TK mengembangan kemampuan mengingat untuk sesuatu yang didengar. Anak mungkin tidak selalu menjadi pendengar yang baik. Hal itu bisa terjadi karena sebagian besar waktu yang dimiliki dipergunakan untuk kegiatan bermain sehingga dirinya tidak sungguh-sungguh dalam mendengar sesuatu, misalnya apa yang disampaikan oleh orang tuanya. Pada umumnya anak

${ }^{1}$ Siti Aisyah dkk, Perkembangan dan Konsep Dasar Pengembangan Anak Usia Dini (Jakarta: Universitas Terbuka, 2007), hlm. 6.

2 Sujiono dan Yuliani Nurani, Konsep Dasar Pendidikan Anak Usia Dini (Jakarta: Indeks, 2009), hlm. 54.

3 Seefeldt, Carol dan Wasik Barbara A, (Terj. Pius Nasar), Pendidikan Anak Usia Dini: Menyiapkan Anak Usia Tiga, Empat, dan Lima Tahun Masuk Sekolah (Jakarta: Indeks, 2008), hlm. 353. 
mendengarkan cerita yang panjang, dengan alur yang menarik dan dalam cerita tersebut terdapat tokoh dengan bermacam-macam karakter. Stimulus seperti itu berguna untuk membangkitkan daya imajinasi anak.

\section{Perkembangan Berbicara}

Untuk belajar bahasa, menurut Dickinson dan Snow anak-anak memerlukan kesempatan untuk bicara dan didengarkan. Pengalaman menyaksikan, mendengarkan, dan terlibat pembicaraan dengan anggota keluarga merupakan pengalaman yang sangat berharga karena anak dapat belajar bahwa situasi yang mereka hadapi menjadi factor yang dipertimbangkan dalam berbicara. ${ }^{4}$

Pada usia 4 - 6 tahun anak sudah mulai mampu berperan serta dalam percakapan yang panjang. Sebagain dari anak-anak ada yang bisa mendominasi pembicaraan. Pada usia ini anak belajar menjadi pengguna bahasa yang kreatif. Anak dapat membuat atau menamakan sesuatu dengan bahasanya sendiri, khususnya untuk hewan atau mainan kesayangannya.

\section{Perkembangan Membaca}

Pembelajaran membaca secara formal belum dilaksanakan pada pendidikan di Taman Kanak-kanak. Apa yang dilakukan di lembaga pendidikan tersebut adalah pengembangan keterampilan agar anak siap untuk belajar membaca. Gambargambar binatang yang ditempel di dinding kelas yang disertai tulisan yang menerangkan tentang binatang apa merupakan stimulus untuk perkembangan kemampuan membaca.

Anak semakin mengenal kata yang sering dia dengar dan mengenal tulisan untuk kata itu, misalnya kata toko, tv dan seterusnya. Setiap saat anak melihat huruf dan rangkaian huruf yang kemudian menimbulkan rasa ingin tahu tentang bagaimana mengucapkannya.

4. Perkembangan Menulis

Sama halnya dengan membaca formal, pembelajaran menulis formal tidak dilaksanakan di taman kanak-kanak, yang dilakukan di taman kanak-kanak berkenaan dengan kemampuan menulis adalah pengembangan kemampuan agar anak siap untuk belajar menulis. Dan untuk itulah maka upaya pengembangan motorik halus dilakukan secara intensif. Perkembangan anak pada motorik halusnya yang semakin meningkat membuat anak mampu menggambar garis lurus, garis tegak, garis lengkung, lingkaran dan sebainya, yang merupakan dasar untuk menggembangkan kemampuan menulis.

\section{Perkembangan Bahasa Anak}

Bahasa dalam bahasa Inggris berarti "language", dalam buku Gleason mengungkapkan Language has been hailed as the hallmark of humanity, the ability that separates humans from animals. ${ }^{5}$ As humans in society, we use our language ability continuously to embrace ideas, share our feelings, comment on the world, and understand each other's minds. Language can be defined as an organized system of

${ }^{4}$ Seefeldt, Carol dan Wasik Barbara, Pendidikan Anak.., hlm. 354.

${ }^{5}$ Berko-Gleason, The development of language, (Boston: Allyn \& Bacon, 1997), hlm. 324. 
arbitrary signals and rule-governed structures that are used as a means for communication. ${ }^{6}$ Bahasa merupakan kemampuan untuk berkomunikasi dengan orang lain. Bahasa merupakan faktor hakiki yang membedakan manusia dengan hewan. Bahasa erat kaitannya dengan perkembangan berfikir individu. Perkembangan berfikir individu tampak dalam perkembangan bahasanya yaitu kemampuan membentuk pengertian, menyusun pendapat dan menarik kesimpulan.

Banyak orang yang mempertukarkan penggunaan istilah "bicara" (speech) dengan bahasa (language), meskipun kedua istilah tersebut sebenarnya tidak sama. ${ }^{7}$ Bahasa mencakup setiap sarana komunikasi dengan menyimbolkan pikiran dan perasaan untuk menyampaikan makna kepada orang lain. Termasuk didalamnya perbedaan bentuk komunikasi yang luas seperti: tulisan, bicara, bahasa simbol, ekspresi muka, isyarat, dan seni. Bicara adalah bentuk bahasa yang menggunakan artikulasi atau kata-kata yang digunakan untuk menyampaikan maksud. Karena bicara merupakan bentuk komunikasi yang paling efektif, penggunaannya paling luas dan paling penting.

Berbicara merupakan alat komunikasi terpenting dalam berkelompok. Anak belajar bagaimana berbicara dengan baik dalam berkomunikasi dengan orang lain. Bertambahnya kosakata yang berasal dari berbagai sumber menyebabkan semakin banyak perbendaharaan kata yang dimiliki. Anak mulai menyadari bahwa komunikasi yang bermakna tidak dapat dicapai bila anak tidak mengerti apa yang dikatakan oleh orang lain. Hal ini mendorong anak untuk meningkatkan pengertiannya. ${ }^{8}$

Sementara pengertian perkembangan (development) merupakan suatu proses yang pasti dialami setiap individu, perkembangan ini adalah bersifat kualitatif dan berhubungan dengan kematangan serta sistematis. Syamsu Yusuf dalam bukunya mendefinisikan perkembangan sebagai perubahan yang progress dan kontinu dalam diri individu dari mulai lahir sampai mati. Yang mana aspekaspek dari perkembangan meliputi : fisik, intelegensi, emosi, bahasa, sosial, kepribadian, moral dan kesadaran beragama. ${ }^{9}$

Bahasa merupakan alat komunikasi bagi setiap orang, termasuk anak-anak. Bahasa yang pertama dikenali anak adalah bahasa ibu. Maka dari itu pemerolehan bahasa merupakan proses yang berlangsung didalam otak seorang anak-anak ketika ia memperoleh bahasa pertamanya atau bahasa ibunya. Agar dapat berbahasa dengan baik dan lancar, anak-anak memerlukan latihan yang intensif dan bertahap. Hal ini sesuai dengan pendapat Soenyono Darjowidjojo bahwa pemerolehan bahasa anak itu tidaklah tiba-tiba atau sekaligus, tetapi bertahap. Kemajuan kemampuan berbahasa mereka berjalan seiring dengan perkembangan fisik, mental, intelektual, dan sosialnya. ${ }^{10}$ Oleh karena itu, perkembangan bahasa

\footnotetext{
${ }^{6}$ Amanda C. Brandone, Language Development, (University of Delaware), hlm. 502.

${ }^{7}$ Elizabeth B. Hurlock, Perkembangan anak, (Jakarta: Erlangga, 1978), hlm. 176.

8 Elizabeth B. Hurlock, Perkembangan anak.., hlm. 362.

9 Yusuf, Syamsu, Psikologi Perkembangan Anak dan Remaja (Bandung : Rosdakarya, 2005),

10 Tarigan dkk, Pendidikan Bahasa dan Sastra Indonesia di Kelas Rendah (Jakarta:
} hlm. 15 . Depdikbud, 1998), hlm. 32. 
anak ditandai oleh suatu rangkaian kesatuan yang bergerak dari bunyi-bunyi atau ucapan yang sederhana menuju tuturan yang lebih kompleks.

Perkembangan bahasa anak itu dipengaruhi oleh bakat bawaan, lingkungan atau faktor lain yang menunjang, yaitu perkembangan fisik dan intelektual. Kemampuan berbahasa sangat penting bagi anak-anak karena anak-anak akan dapat mengembangkan kemampuan sosialnya melalui berbahasa. Keterampilan bergaul dalam lingkungan sosial dimulai dengan penguasaan kemampuan berbahasa. Melalui bahasa, anak dapat mengekspresikan pikiran, sehingga orang lain memahaminya dan menciptakan suatu hubungan sosial. Jadi, tidaklah mengherankan bahwa bahasa dianggap sebagai salah satu indikator kesuksesan seorang anak. ${ }^{11}$

\section{Teori Perkembangan Bahasa Anak}

Berbagai pendapat tentang teori pengembangan bahasa dikemukakan oleh para ahli. Pemahaman akan berbagai teori pengembangan bahasa dapat memengaruhi penerapan metode implementasi terhadap pengembangan bahasa anak. Beberapa teori mengenai hal ini antara lain, yaitu:

\section{Teori Behaviorisme ${ }^{12}$}

Kaum behaviorisme menerangkan bahwa proses pemerolehan bahasa pertama dikendalikan dari luar diri si anak, yaitu oleh rangsangan yang diberikan melalui lingkungan. Istilah bahasa bagi kaum behaviorisme dianggap kurang tepat karenan istilah bahasa itu menyiaratkan suatu wujud, sesuatu yang dimiliki atau digunakan, dan bukan sesuatu yang dilakukan. Padahal bahasa itu merupakan salah satu perilaku, di antara perilaku-perilaku manusia lainnya. Menurut kaum behaviorisme kemampuan berbicara dan memahami bahasa oleh anak diperoleh melalui rangsangan dari lingkungannya. Anak dianggap sebagai penerima pasif dari tekanan lingkungannya, tidak memiliki peranan yang aktif di dalam proses perkembangan perilaku verbalnya. Bahkan kaum behaviorisme tidak mengakui kematangan anak dalam pemerolehan bahasa.

Kaum behaviorisme tidak mengakui pandangan bahwa anak menguasai kaidah bahasa dan memiliki kemampuan untuk mengabstrakkan ciri-ciri penting dari bahasa di lingkungannya. Mereka berbendapat rangsangan (stimulus) dari lingkungan tertentu memperkuat kemampuan berbahasa anak. Perkembangan bahasa mereka pandang sebagai suatu kemajuan dari pengungkapan verbal yang berlaku secara acak sampai ke kemampuan yang sebenarnya untuk berkomunikasi melalui prinsip pertalian S - P (stimulus - respon) dan proses peniruan-peniruan.

Skinner, mendefinisikan bahwa pembelajaran dipengaruhi oleh perilaku yang dibentuk oleh lingkungan eksternalnya, artinya pengetahuan merupakan hasil dari interaksi dengan lingkungannya melalui pengondisian stimulus yang menimbulkan respons. Perubahan lingkungan pembelajaran dapat memengaruhi pikiran, perasaan, dan perilaku anak secara bertahap. Perilaku positif pada anak cenderung akan diulang ketika mendapat dorongan yang sesuai dengan

11 Syawal Gultom, Modul Bahasa Indonesia : Karakteristik perkembangan anak (Jakarta: pusat pengembangan profesi pendidik, 2005), hlm. 13-14.

${ }^{12}$ Abdul Chear, Psikolinguistik kajian Teori, (Jakarta: Rineka Cipta, 2002), hlm. 45. 
kemampuan anak dari lingkungannya. Latihan untuk anak harus menggunakan bentuk-bentuk pertanyaan (stimulus) dan jawaban (respons) yang dikenalkan secara bertahap, mulai dari yang sederhana sampai pada yang lebih rumit.

\section{Teori Nativisme ${ }^{13}$}

Nativisme berpendapat bahwa selama proses pemerolehan bahasa pertama, kanak-kanak (manusia) sedikit demi sedikit membuka kemampuan lingualnya yang secara genetis telah diprogramkan. Pandangan ini tidak mengangggap lingkungan punya pengaruh dalam pemerolehan bahasa, melainkan mengganggap bahwa bahasa merupakan biologis, sejalan dengan yang disebut "hipotesis pemberian alam". Kaum nativis berpendapat bahwa bahasa itu terlalu kompleks dan rumit, sehingga mustahil dapat dipelajari dalam waktu singkat melalui metode seperti "peniruan" (imitation). Jadi, pasti ada beberapa aspek penting mengenai system bahasa yang sudah ada pada manusia secara alamiah.

Menurut Chomsky bahasa hanya dapat dikuasai oleh manusia, Binatang tidak mungkin dapat menguasai bahasa manusia. Pendapat ini didasarkan pada asumsi. Pertama, perilaku bahasa adalah sesuatu yang diturunkan (genetik); pola perkembangan bahasa adalah sama pada semua macam bahasa dan budaya (merupakan sesuatu yang universal); dan lingkungan hanya memiliki peran kecil di dalan proses pematangan bahasa. Kedua, bahasa dapat dikuasai dalam waktu singkat, anak berusia empat tahun sudah dapat berbicara mirip dengan orang dewasa. Ketiga, lingkungan bahasa si anak tidak dapat menyediakan data secukupnya bagi penguasaan tata bahasa yang rumit dari orang dewasa.

Lebih lanjut Chomsky mengemukakan bahwa, seorang anak dibekali "alat pemerolehan bahasa" (language acquisition device (LAD). Alat yang merupakan pemberian biologis yang sudah diprogramkan untuk merinci butir-butir yang mungkin dari suatu tata bahasa, dan dianggap sebagai bagian fisiologis dari otak yang khusus untuk memproses bahasa, yang tidak punya kaitannya dengan kemempuan kognitif lainnya.

\section{Teori Kognitivisme ${ }^{14}$}

Istilah kognitif berkaitan dengan peristiwa mental yang terlibat dalam proses pengenalan tentang dunia, yang sedikit banyak melibatkan pikiran atau berpikir. Oleh karena itu, secara umum kata kognisi biasa dianggap bersinonim dengan kata berpikir atau pikiran. Piaget menyatakan adanya beberapa tahap dalam perkembangan kognitif anak. Tahap itu, yaitu : (a) Tahap sensomontorik.

Tahap ini merupakan tahap pertama dalam perkembangan kognisi anak dan berlangsung pada sebagaian dari dua tahun pertama dalam kehidupannya, lalu pada tahun kedua muncul koordiansi dari kedua kemampuan awal ini. Pada akhirnya periode sensorik bayi dapat berpikir tentang dunia, yaitu yang berhungan dengan pengalaman-pengalaman dan tindakan-tindakan yang sederhana, (b)Tahap pra-operasional. Pada tahap ini cara "berfikir" anak-anak masih didominasi oleh cara bagaimana hal-hal atau benda-benda itu tampak. Cara berfikirnya masih kurang operasional, (c) Tahap operasional konkret. Pada tahap

\footnotetext{
${ }^{13}$ Nanik Setyawati, Teori Balajar Bahasa (Semarang: IKIP PGRI, 2009), hlm. 12.

14 Yusuf, Syamsu, Psikologi Perkembangan Anak dan Remaja (Bandung : Rosdakarya, 2005), hlm. 171.
} 
ini anak-anak telah memahami konsep konvensi.Tahap ini dilalui anak yang berusia sekitar tujuh sampai dengan menjelang sebelas tahun, dan (d) Tahap operasional formal.

Pada tahap ini dilalui anak setelah anak berusia 11 tahun ke atas, anak-anak sudah berfikir logis seperti halnya dengan orang dewasa. Mereka merumuskan dan mengetes hipitesis-hipotesis yang rumit mereka berfikir abstrak dan mereka menggeneralisasikan dengan menggunakan konsep yang abstrak, dari satu situasi ke situasi yang lain.

\section{Tahap-Tahap Perkembangan Bahasa pada Anak}

Menurut pendapat Piaget mengemukakan bahwa proses perkembangan anak dari kecil hingga dewasa melalui empat tahap perkembangan, ${ }^{15}$ yaitu:

1. Tahap Sensori Motor (0-2 Tahun)

Pada tahap ini, kegiatan intelektual anak hampir seluruhnya merupakan gejala yang diterima secara langsung melalui indera. Pada saat anak mencapai kematangan dan secara perlahan mulai memperoleh keterampilan berbahasa, mereka menerapkannya pada objek-objek yang nyata. Pada tahap ini anak mulai memahami hubungan antara benda dengan nama benda tersebut

\section{Tahap Praoperasional (2-7 Tahun)}

Perkembangan yang pesat dialami oleh anak pada tahap ini. Anak semakin memahami lambang-lambang bahasa yang digunakan untuk menunjukkan bendabenda. Keputusan yang diambil hanya berdasarkan intuisi, bukan atas dasar analisis rasional. Kesimpulan yang diambil merupakan kesimpulan dari sebagian kecil yang diketahuinya, dari suatu keseluruhan yang besar. Anak akan berpendapat bahwa pesawat terbang berukuran kecil karena itulah yang mereka lihat di langit ketika ada pesawat terbang yang lewat.

3. Tahap Operasional Konkret (7-11 Tahun)

Pada tahap ini anak mulai berpikir logis dan sistematis untuk mencapai pemecahan masalah. Masalah yang dihadapi dalam tahap ini bersifat konkret. Anak akan merasa kesulitan bila menghadapi masalah yang bersifat abstrak. Pada tahap ini anak menyukai soal-soal yang telah tersedia jawabannya.

4. Tahap Operasional Formal (11-15 Tahun)

Anak mencapai tahap perkembangan ini ditandai dengan pola pikirnya yang seperti orang dewasa. Anak telah dapat menerapkan cara berpikir terhadap permasalahan yang konkret maupun abstrak. Pada tahap ini anak sudah dapat membentuk ide-ide dan berpikir tentang masa depan secara realistis.

Sedangkan Johan Amos Comenius dalam Kartini Kartono berpendapat bahwa perkembangan bahasa seseorang terdiri dari empat periode perkembangan, yaitu: ${ }^{16}$

15 Mulyani Sumantri dan nana syaodiah, perkembangan peserta didik, (Jakarta: Universitas terbuka, 2009), hlm. 1-15. 
1. Periode Sekolah-Ibu (0-6 Tahun). Pada periode ini hampir semua usaha bimbingan-pendidikan berlangsung di lingkungan keluarga, terutama aktivitas ibu sangat mempengaruhi proses perkembangan anak.

2. Periode Sekolah-Bahasa-Ibu (6-12 Tahun). Pada periode ini anak baru mampu menghayati setiap pengalaman dengan pengertian bahasa sendiri (bahasa ibu). Bahasa ibu ini digunakan untuk berkomunikasi dengan orang lain, yaitu untuk mendapatkan impresi dari luar berupa pengaruh, sugesti serta transmisi kultural dari orang dewasa, dan untuk mengekspresikan kehidupan batinnya kepada orang lain.

3. Periode Sekolah-Latin (12-18 Tahun). Pada periode ini anak mulai diajarkan bahasa latin sebagai bahasa kebudayaan. Bahasa ini perlu diajarkan kepada anak agar anak mencapai taraf beradab dan berbudaya.

4. Periode Sekolah-Universitas (18-24 Tahun). Pada periode yang terakhir ini anak muda mengalami proses pembudayaan dengan menghayati nilai-nilai ilmiah, di samping mempelajari macam-macam ilmu pengetahuan.

Khusus mengenai perkembangan bahasa anak, Conny R. Semiawan berpendapat bahwa tahap perkembangan bahasa anak terdiri dari empat tahap, yaitu: 17

1. Perkembangan Bahasa Usia Bayi

Secara umum bayi mulai mengeluarkan ucapan pada saat usianya 10-16 bulan, walaupun pada kenyataannya ada juga yang memerlukan waktu lebih lama dari itu. Sebelum anak-anak mengucapkan kata-kata, terlebih dahulu membuat ocehan misalnya dengan ucapan baa, maa atau paa. Mengoceh ini mulai terjadi saat usia sekitar 3-6 bulan. Tujuan komunikasi yang dilakukan oleh bayi pada usia dini ialah untuk menarik perhatian orang tua dan orang lain yang ada di sekitarnya. Pada umumnya, bayi menarik perhatian orang lain dengan membuat kontak mata, membunyikan ucapan, serta menggerak-gerakkan tangan. Biasanya kata-kata anak yang pertama kali muncul adalah nama-nama orang penting yang ada disekitarnya, nama-nama binatang, dan benda-benda lain yang ada di sekitarnya. Anak-anak yang telah memasuki usia 18-24 bulan mulai mengucapkan pernyataan dengan dua kata.

\section{Perkembangan Bahasa Anak Usia Dini}

Beberapa anak usia pra sekolah memiliki kesulitan dalam mengucapkan kelompok konsonan, misalnya untuk mengucapkan kata setrika, mangga, dan lain-lain. Pada usia ini, anak-anak sudah dapat mengembangkan ungkapannya lebih dari dua kata-kata setiap kalimatnya. Anak-anak mulai berbicara dengan urutan kata yang menunjukkan suatu pendalaman yang meningkat terhadap aturan yang komplek tentang urutan kata-kata yang diucapkan. Pada usia ini anak-anak juga sudah mulai mampu mengembangkan pengetahuan tentang makna dengan cepat.

${ }^{16}$ Kartini Kartono, Psikologi Anak: Psikologi Perkembangan (Bandung: CV. Mandar Maju, 2007), hlm. 34-35.

17 Conny R. Semiawan, Perkembangan dan Belajar Peserta Didik. (Jakarta: Departemen Pendidikan dan Kebudayaan Direktorat Jenderal Pendidikan Tinggi, 2000), hlm. 128-136. 


\section{Perkembangan Bahasa Usia Sekolah}

Pada tahap ini penekanan perkembangan berubah dari bentuk bahasa ke isi dan penggunaan bahasa. Anak-anak telah mencapai tahap kreatif dalam perkembangan bahasa. Bahasa kreatif anak dapat didengar dalam bentuk nyanyian atau sajak.

\section{Perkembangan Membaca dan Menulis}

Salah satu faktor yang berpengaruh pada perkembangan membaca anak usia dini ialah kesediaan orang tua untuk menyediakan bahan bacaan dan menciptakan suasana yang kondusif bagi perkembangan kemampuan membaca anak. Kegiatan membaca yang dilakukan secara alamiah dalam suasana kehidupan sosial memiliki efektifitas yang tinggi untuk peningkatan kemampuan membaca pada anak. Anak usia tujuh atau delapan tahun telah memperoleh pengetahuan tentang huruf, suku kata dan kata. Siswa kelas tiga dan empat sudah mampu menganalisis kata-kata baru dengan menggunakan pola orthograpik dan inferensi kontekstual. Siswa kelas lima dan enam sudah mulai membaca dari keterampilan decoding menuju ke pemahaman.

\section{Faktor yang Memengaruhi Perkembangan Bahasa pada Anak}

Dalam kehidupan perkembangan anak, banyak faktor yang dapat mempengaruhi jalannya perkembangan anak,mulai dari perkembangan tubuh anak hingga faktor perkembangan bahasa anak yang biasanya mengalami permasalahan atau kendala sehingga menjadikan anak mengalami keterlambatan komunikasi pada umumnya.

Faktor perkembangan bahasa anak dapat di sebabkan oleh banyak faktor antaran lain yaitu :

1. Tingkat pendidikan orang tua

Tingkat pendidikan merupakan salah satu faktor dari kualitas pengasuhan anak. Penelitian oleh NICHD menyimpulkan bahwa anak yang mendapatkan pengalaman perawatan dengan kualitas yang tinggi secara konsisten menunjukkan fungsi kognitif dan perkembangan bahasa yang lebih baik sepanjang tiga tahun pertama kehidupannya. ${ }^{18}$ Penelitian Pancsofar dan Vemon-Feagans, menemukan bahwa tingkat pendidikan orangtua mempunyai pengaruh yang bermakna pada kemampuan bicara dan bahasa anaknya, sebab memberi dampak pada pola bahasa dalam keluarga. ${ }^{19}$ Zadeh dan Bolter, menyatakan tingkat pendidikan orangtua dan pola pikir orangtua yang tradisional yang bersifat negatif seperti seorang anak harus mengikuti perintah orangtuanya tanpa boleh bertanya atau mengharapkan kepatuhan sepenuh dari anaknya, memiliki hubungan yang tinggi. Mereka menyimpulkan bahwa orangtua dengan tingkat pendidikan yang rendah lebih cenderung untuk memiliki pola pikir tradisonal, sehingga bersikap otoriter kepada anaknya yang nantinya akan menghambat perkembangan bahasa dan bicara anak, dan selanjutnya mempengaruhi prestasi anak tersebut.

18 Pancsofar N, Vemon-Feagans L, Mother and father language input to young children: contributions to later language development (J Appl Dev Psy, 2006), hlm. 27.

19 Zadeh ZY, Bolter-Im N, Parenting beliefs and academic achievement: the mediation role of language (Canada: Canadian Pshycological Association Ottawa, 2007), hlm. 232. 
2. Faktor ekonomi orang tua

Faktor ekonomi orang tua sangat mempengaruhi perkembangan bahasa pada anak-anak seperti yang diungkapkan $A$ family history of language and learning problems, and low socioeconomic status are each associated with language impairment. ${ }^{20}$ Beberapa studi tentang hubungan antara perkembangan bahasa dengan status sosial ekonomi keluarga menunjukkan bahwa anak yang berasal dari keluarga miskin mengalami kelambatan dalam perkembangan bahasa dibandingkan dengan anak yang berasal dari keluarga yang lebih baik. Kondisi ini terjadi mungkin disebabkan oleh perbedaan kecerdasan atau kesempatan belajar (keluarga miskin diduga kurang memperhatikan perkembangan bahasa anaknya), atau kedua-duanya.

3. Hubungan Keluarga

Hubungan ini dimaknai sebagai proses pengalaman berinteraksi dan berkomunikasi dengan lingkungan keluarga, terutama dengan orang tua yang mengajar, melatih dan memberikan contoh berbahasa dengan anak. Hubungan yang sehat antara orang tua dan anak memfasilitasi perkembangan bahasa anak, sedangkan hubungan yang tidak sehat menakibatkan anak akan mengalami kesulitan atau kelambatan dalam perkembangan bahasanya. Hubungan yang sehat itu bisa berupa sikap orang tua yang keras atau kasar, kurang kasih sayang dan kurang perhatian untuk memberikan latihan dan contohdalam berbahasa yang baik kepada anak, maka perkembangan bahasa anak cenderung akan mengalami stagnasi atau kelainan. Seperti gagap dalam berbicara, tidak jelas dalam mengungkapkan kata-kata, merasa takut untuk mengungkapkan pendapat, dan berkata yang kasar atau tidak sopan. ${ }^{21}$

4. Kesehatan

Anak yang sehat lebih cepat belajar berbicara ketimbang anak yang tidak sehat, karena motivasinya lebih kuat untuk menjadianggauta kelompok sosial dan berkomunikasi dengan anggauta kelompok tersebut. Apabila pada usia dua tahun pertama, anak mengalami sakit terus menerus, maka anak tersebut cenderungakan mengalami kelambatan atau kesulitan dala perkembangan bahasannya. ${ }^{22}$

5. Metode Pelatihan Anak

Anak-anak yang dilatih secara otoriter yang menekankan bahwa "anak harus dilihat dan didengar" merupakan hambatan belajar. Sedangkan pelatihan yang memberikan keleluasan dan demokratis akan mendorong anak untuk belajar. ${ }^{23}$

\section{Kesimpulan}

Bahasa merupakan kemampuan untuk berkomunikasi dengan orang lain. Bahasa merupakan faktor hakiki yang membedakan manusia dengan hewan. Bahasa erat kaitannya dengan perekembangan berfikir individu. Perkembangan berfikir individu tampak dalam perkembangan bahasanya yaitu kemampuan membentuk

${ }^{20}$ Amanda C. Brandone, Language Development (University of Delaware, 1993), hlm. 511.

21 Yusuf, Syamsu, Psikologi Perkembangan Anak dan Remaja (Bandung : Rosdakarya, 2005), hlm. 34.

22 Yusuf, Syamsu, Psikologi Perkembangan.., hlm. 35.

${ }^{23}$ Yusuf, Syamsu, Psikologi Perkembangan.., hlm. 37. 
pengertian, menyusun pendapat dan menarik kesimpulan. Sedangkan, perkembangan merupakan suatu proses yang pasti dialami setiap individu, perkembangan ini adalah bersifat kualitatif dan berhubungan dengan kematangan serta sistematis. Perkembangan bahasa pada anak sangatlah penting karena melalui bahasa, anak dapat mengekspresikan pikiran, sehingga orang lain memahaminya dan menciptakan suatu hubungan sosial. Jadi, tidaklah mengherankan bahwa bahasa dianggap sebagai salah satu indikator kesuksesan seorang anak.

Implikasi perkembangan bahasa anak terhadap segi pendidikan salah satunya adalah terhadap penyelenggaraan pendidikan. Sebagai individu yang sedang tumbuh dan berkembang, maka proses pertumbuhan dan perkembangan peserta didik sangat dipengaruhi oleh perkembangan bahasa. Bahasa merupakan sebuah pengantar. Jika telah memahami bahasa maka tidak akan sulit bagi anak untuk menerima pesan ataupun kata-kata yang diucapkan oleh seorang guru. Karena Perkembangan bahasa adalah merupakan proses alamiah yang difasilitasi oleh kesempatan-kesempatan memanfaatkan bahasa dalam aktivitas sehari-hari. Para guru dapat mengintruksikan kepada para siswa untuk mengekspresikan dirinya secara verbal dan dalam bentuk tulisan ketika mereka memecahkan persoalan dan menyelesaikan tugas-tugas akademik. Jadi perkembangan bahasa sangat penting dalam penyelenggaraan proses pendidikan disekolah. Perkembangan bahasa sangat penting karena Melalui bahasa, anak dapat mengekspresikan pikiran, sehingga orang lain memahaminya dan menciptakan suatu hubungan sosial. Jadi, tidaklah mengherankan bahwa bahasa dianggap sebagai salah satu indikator kesuksesan seorang anak.

\section{Bibliografi}

Berko-Gleason, The development of language, Boston: Allyn \& Bacon, 1997.

BPS Provinsi Kalimantan Selatan, Berita resmi statistik provinsi Kalimantan Selatan: tingkat kemiskinan di Kalimantan Selatan Maret 2008 - Maret 2009. No.21/07/63/ Th.XII., 1 Juli 2009.

Brandone . Amanda. C, Language Development. University of Delaware, 2007.

Chear, Abdul, Psikolinguistik kajian Teori. Rineka Cipta: Jakarta, 2002.

Conny R. Semiawan, Perkembangan dan Belajar Peserta Didik. Jakarta: Departemen Pendidikan dan Kebudayaan Direktorat Jenderal Pendidikan Tinggi, 1999.

Elizabeth B. Hurlock, Perkembangan anak, Jakarta: Erlangga, 1978.

Gultom. Syawal, Modul Bahasa Indonesia: Karakteristik perkembangan anak. Jakarta: pusat pengembangan profesi pendidik, 2005.

Kartono. Kartini, Psikologi Anak (Psikologi Perkembangan), Bandung: CV. Mandar Maju, 2007. 
N. Pancsofar, L. Vemon-Feagans, Mother and father language input to young children: contributions to later language development. J Applied Dev Psychology, 2006.

Setyawati, Nanik, Teori Balajar Bahasa. Semarang: IKIP PGRI, 2009.

Sumantri, Mulyani, Syaodiah, Nana, Perkembangan Peserta Didik. Jakarta: Universitas Terbuka, 2009.

Tarigan., Djago dkk, Pendidikan Bahasa dan Sastra Indonesia di Kelas Rendah, Jakarta: Depdikbud, 1998.

W. Santrock, John, Life Span Development: Perkembangan Masa Hidup, Edisi 5 jilid 1. Jakarta: Erlangga, 2007.

W. Santrock, John, Perkembangan Anak, Jakarta: Erlangga, 2007.

Yusuf, Syamsu, Psikologi Perkembangan Anak dan Remaja, Bandung: Rosdakarya, 2005.

Zadeh ZY, Bolter-Im N, Parenting beliefs and academic achievement: the mediation role of language. Canadian Pshycological Association Ottawa, Canada, 2007. 